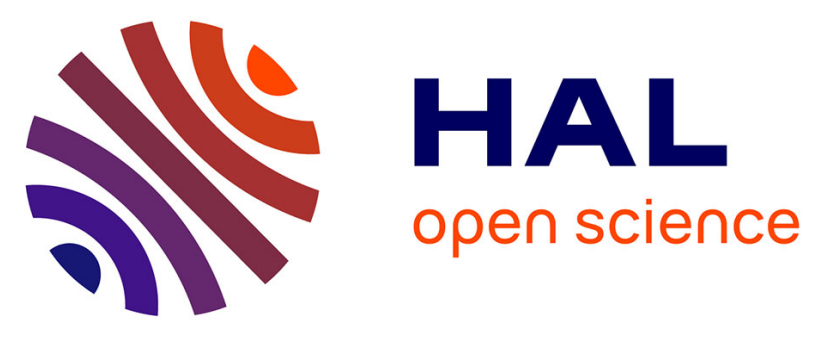

\title{
Effect of changes in the nutritional status on the performances of growing creole kids during an established nematode parasite infection
}

Willy Cei, Harry Archimède, Rémy Arquet, Yoann Felicite, Dalila Feuillet, Angebert Népos, Pierre Mulciba, Tatiana Silou-Etienne, Gisèle Alexandre, Jean-Christophe Bambou

\section{To cite this version:}

Willy Cei, Harry Archimède, Rémy Arquet, Yoann Felicite, Dalila Feuillet, et al.. Effect of changes in the nutritional status on the performances of growing creole kids during an established nematode parasite infection. Tropical Animal Health and Production, 2017, 49 (4), pp.765-770. 10.1007/s11250017-1258-z . hal-01607581

\section{HAL Id: hal-01607581 \\ https://hal.science/hal-01607581}

Submitted on 26 May 2020

HAL is a multi-disciplinary open access archive for the deposit and dissemination of scientific research documents, whether they are published or not. The documents may come from teaching and research institutions in France or abroad, or from public or private research centers.
L'archive ouverte pluridisciplinaire HAL, est destinée au dépôt et à la diffusion de documents scientifiques de niveau recherche, publiés ou non, émanant des établissements d'enseignement et de recherche français ou étrangers, des laboratoires publics ou privés.

\section{다(1)(2)}

Distributed under a Creative Commons Attribution - ShareAlikel 4.0 International 


\title{
Effect of changes in the nutritional status on the performances of growing Creole kids during an established nematode parasite infection
}

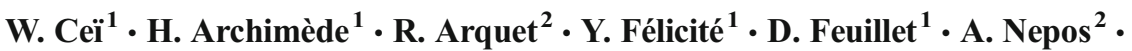 \\ P. Mulciba ${ }^{2}$. T. Etienne ${ }^{1}$ - G. Alexandre ${ }^{1}$ - J. C. Bambou ${ }^{1,3}$
}

Received: 3 August 2016 / Accepted: 23 February 2017

(C) Springer Science+Business Media Dordrecht 2017

\begin{abstract}
In this study, we evaluated the effect of changes in the nutritional status on the performances of growing Creole kids during an established experimental gastrointestinal nematode (GIN) infection. Eighteen 6-month-old Creole kids were distributed in two main groups infected (I) and non-infected (NI) and were placed for a period of 4 weeks on each of three diets differing in their nutritional values: (1) fresh grass (FG, $6.7 \mathrm{MJ} / \mathrm{kg}$ dry matter (DM) and $7.9 \%$ crude protein $(\mathrm{CP})$ ) nonsupplemented, (2) FG supplemented with a commercial concentrate (CC, $12.2 \mathrm{MJ} / \mathrm{kg}$ DM and $20.6 \%$ of CP), and (3) FG supplemented with dried banana (Ban, $11.1 \mathrm{MJ} / \mathrm{kg} \mathrm{DM}$ and $4.3 \% \mathrm{CP})$. The experiment was designed as a split-plot with experimental infection (I and NI) as the main plot and the diets (FG, CC, and Ban) as the subplots with three replicates. We showed a significant effect of the diet changes on the fecal egg counts. A higher dry matter intake, digestibility, and growth rate were observed with the $\mathrm{CC}$ diet but together with a slight but significant increase of the intensity of the GIN infection. These data suggest that the improvement of the protein nutritional status during an establish GIN infection would improve the animal performance at the expense of the mechanism involved in the control of the infection.
\end{abstract}

Keywords Nutrition $\cdot$ Parasitism $\cdot$ Small ruminant $\cdot$ Growth performance $\cdot$ Infection

J. C. Bambou

Jean-Christophe.Bambou@inra.fr

1 URZ, Unité de Recherches Zootechniques, INRA, 97170 Petit-Bourg, Guadeloupe, France

2 PTEA, Plateforme Tropicale d'Expérimentation sur l'Animal, UE1294, 97170 Petit-Bourg, Guadeloupe, France

3 INRA-URZ, 97170 Petit-Bourg, France

\section{Introduction}

Gastrointestinal nematode (GIN) infections are among the most common and economically important pathogenic constraints on efficient grazing small ruminant production system (Bishop 2012; Charlier et al. 2014). The rise of anthelmintic resistance during the past decades and public concern about chemical residues in animal products have increased the need for alternative control strategies (Jackson and Coop 2000; Papadopoulos 2008). There is accumulating evidence showing that the nutritional status is closely associated with the capacity of the host to mount an efficient immune response against invading pathogens and more singularly against GIN (Adams 2006; Colditz 2008). Thus, nutritional manipulation of small ruminants has long been considered as a tool for the control of GIN infections (Hoste et al. 2016). Numerous feeding trials with small ruminants have paid much attention on the effects of an increased nutrients supply (in protein and/or energy) on the host response to GIN infections (Houdijk 2012). It has been shown that an improved nutritional status could reduce the production losses and mortality rates due to GIN infection (Athanasiadou et al. 2008). Most of the studies investigating the underlying mechanisms show that the nutritional status is closely correlated with the host immune response involved in regulating GIN establishment, fecundity, and survival rates (Athanasiadou et al. 2008; Athanasiadou and Houdijk 2010).

In tropical countries, the variation of feed resources availability and quality lead to seasonal recurrent deteriorated nutritional status (Aumont et al. 1995; Archimede et al. 2011). However, in most of the studies, the effect of the nutritional status is evaluated either concomitantly with the infection or before the infection (i.e., the carry-over effect). To our knowledge, the potential beneficial or detrimental effects of nutritional status changes during an establish GIN infection have 
never been addressed. In this study, we evaluated the effect of changes in the nutritional status on the performances of growing Creole kids during an established experimental Haemonchus contortus infection.

\section{Materials and methods}

The experiment was conducted at the Institut National de la Recherche Agronomique (INRA) Plateforme Tropicale d'Expérimentation sur l'Animal (PTEA Gardel), Guadeloupe $\left(16^{\circ} 17^{\prime}\right.$ latitude north, $61^{\circ} 32^{\prime}$ longitude west). All animal care, handling techniques, procedures, as well as license for experimental infection and blood sampling were approved by INRA, according to the certificate number A-971-18-01 of authorization to experiment on living animals issued by the French Ministry of Agriculture, before the initiation of the research.

\section{Animals, management, and experimental design}

The study was carried out with growing male 6-month-old Creole kids $(n=18)$ born and reared outdoors at PTEA Gardel on pastures based on Digitaria decumbens and Brachiaria purpurascens irrigated if needed and fertilized $(0.5 \mathrm{~kg} \mathrm{~N} / \mathrm{ha} /$ day). Four weeks before the experimental infection, the kids were drenched with ivermectin (Oramec, Merial, Lyon, France, $0.3 \mathrm{mg} / \mathrm{kg}$ body weight (BW)), levamisole (Polystrongle, Merial, Lyon, France $7.5 \mathrm{mg} / \mathrm{kg} \mathrm{BW}$ ), and toltrazuril (Baycox Ovis, Bayer HealthCare, Loos, France, $20 \mathrm{mg} / \mathrm{kg} \mathrm{BW}$ ); housed under worm-free conditions in individual pens $(2.0 \times 1.0 \mathrm{~m})$; and fed with $300 \mathrm{~g} / \mathrm{kids}$ of a mix of supplements (50:50) of commercial concentrate (CC) and dried banana (Ban). The parasite-free fresh grass $(\mathrm{FG})$ was proposed ad libitum. During this period, the fecal egg counts (FEC) remained at zero (1 FEC/week/animal). The day of the experimental infection, two groups of kids were randomly constituted (infected and non-infected; $n=9$ per group; $11.83 \pm 2.44$ and $12.32 \pm 1.88 \mathrm{~kg} \mathrm{BW}$, respectively). The experimental infection was performed with an oral single dose of $10 \mathrm{ml}$ of tap water containing 500 third-larva stage (L3) $/ \mathrm{kg}$ BW of Haemonchus contortus and Trichostrongylus colubriformis $(60 \%$ H. contortus and $40 \%$ T. colubriformis). The L3 were obtained 42 days before the experimental infection from cultures of feces taken from Creole goats at pasture at PTEA Gardel. The non-infected kids were sham infected with $10 \mathrm{ml}$ of tap water. Kids in each group were used in a balanced $2 \times 3$ factorial split-plot design with three 4 -week periods from the experimental infection. Each period of 4 weeks consisted of 2 weeks of adaptation to the diet, followed by 2 weeks of measures (intake, digestibility, FEC, and packed cell volume (PCV)). The experiment lasted for 12 weeks in total. The feed intake, the growth rate (average daily gain (ADG)), the FEC, and the PCV were monitored weekly. The digestibility of the diets was measured during the periods corresponding to 3 and 4, 7 and 8 , and 11 and 12 weeks post-infection.

\section{Diets and feedings}

The two supplements (CC and Ban; Table 1) were balanced in energy and protein as follow: (1) $12.2 \mathrm{MJ} / \mathrm{kg}$ dry matter (DM) and $20.6 \%$ of crude protein (CP) (commercial concentrate (CC)), (2) $11.1 \mathrm{MJ} / \mathrm{kg} \mathrm{DM}$, and $4.3 \% \mathrm{CP}$ (dried banana (Ban)). The quantity of supplements (CC and Ban) offered was adjusted on the energy basis to reach the same level of energetic supplementation ( 270 and $300 \mathrm{~g} /$ day/animal for CC and Ban, respectively). The FG was on average at $6.7 \mathrm{MJ} / \mathrm{kg}$ $\mathrm{DM}$ and $7.9 \% \mathrm{CP}$. The supplements (CC or Ban) were distributed at 7 a.m. and the FG at 10 a.m. and 3 p.m. (50\% of the daily allowance at each meal). The grass was cut daily $3 \mathrm{~cm}$ above the ground with the same mowing machine (BCS S.p.A., Milan, Italy) at 7 a.m. and then chopped into $5-\mathrm{cm}$ lengths using an electric chopper (Dessertine-Hupin S.A., Buxière Les Mines, France).

\section{Feed intake and in vivo total tract digestibility}

As previously described, total feces collection was performed with fecal trays placed behind the kids (Bambou et al. 2009). Briefly, pooled samples of FG, supplements, and feces (10\% per day of the wet weight) were daily collected for chemical analyses. For each digestibility measurement week, a 5-day period for sample collection was carried out. Offered and refused feed were individually recorded weekly in order to determine voluntary dry matter intake (DMI). The in vivo apparent total tract $\mathrm{DM}$, organic matter (OM), $\mathrm{CP}$, neutral detergent fiber (NDF), acid detergent fiber (ADF), and Amidon digestibilities were determined.

\section{Chemical analyses and analytical procedures}

The DM contents of feeds, orts, and feces were determined by oven drying (type SE-79, Le Matériel Physic Chimique Flam et Cie, MPC, Neuily S/Marine, France) to a constant weight at $60{ }^{\circ} \mathrm{C}$ for $48 \mathrm{~h}$ while ash content was determined by heating samples at $550{ }^{\circ} \mathrm{C}$ for $4 \mathrm{~h}$; thereafter, the $\mathrm{OM}$ content was calculated by difference (AOAC 1997). Dry samples were obtained for further chemical analyses and were ground (model SK100 confort Gußeisen, F. Kurt Retsch GmbH \& Co, Haan, Germany) to pass through a 1-mm stainless steel screen. The $\mathrm{CP}$ content was calculated after $\mathrm{N}$ determination by combustion using the micro-Dumas method (NA2100 Protein, CE Instruments, ThermoQuest S.p.A., Milano, Italy).

The methods of Vansoest et al. (1991) were followed to determine NDF and ADF (sequentially) on an ash-free basis using the $\mathrm{ANKOM}^{200}$ Fiber Analyzer incubator (ANKOM 
Table 1 Chemical composition and nutritional values of the supplements and the fresh grass

\begin{tabular}{lccl}
\hline Item $\%$ & $\mathrm{CC}$ & Dried banana & FG \\
\hline $\mathrm{DM}$ & 92.0 & 83.4 & 28.3 \\
$\mathrm{OM}$ & 85.0 & 94.3 & 87.9 \\
$\mathrm{CP}$ & 20.6 & 4.3 & 7.9 \\
$\mathrm{NDF}$ & 18.2 & 15.3 & 67.7 \\
$\mathrm{ADF}$ & 4.0 & 8.0 & 37.2 \\
$\mathrm{ADL}$ & 0.4 & 3.7 & 4.6 \\
Amidon & 37.2 & 70.7 & 0 \\
ME (MJ/kg DM) & 12.2 & 11.1 & 6.7 \\
\hline
\end{tabular}

$C C$ commercial concentrate (ingredients: soybean meal, wheat bran, maize), $F G$ fresh grass, $O M$ organic matter, $C P$ crude protein, $N D F$ neutral detergent fiber, $A D F$ acid detergent fiber, $A D L$ acid detergent lignin, $M E$ metabolizable energy

Technology, Fairport, NY). The hemicellulose and cellulose contents of ingredients were calculated as the differences between NDF and ADF and ADF and ADL, respectively.

\section{Fecal egg count and blood sampling}

To determine FEC, fecal samples of approximately $10 \mathrm{~g}$ were weekly collected directly from the rectum of each kid. The feces were kept in plastic tubes to avoid contamination and immediately transported to the laboratory in refrigerated vials. All samples were individually analyzed using a modified McMaster method for rapid determination, and FEC was expressed as the number of eggs per gram of feces (Aumont et al. 1997). Blood samples were individually collected once a week by jugular venipuncture from each Creole kid by using disposable syringes and 20-ga needles. A 2.5-ml portion of each blood sample was placed in commercial anticoagulant tubes (ethylenediaminetetraacetic acid $\left(\mathrm{K}_{3}\right.$ EDTA) tubes; Becton Dickinson, Plymouth, UK). Blood samples previously placed in EDTA-coated tubes were used to measure the PCV with the capillary microhematocrit method (Goldsmid 1970).

\section{Calculation and statistical analysis}

Data (PCV, FEC, nutrient digestibility, body weight gain, and diet digestibility) collected simultaneously from infected and non-infected animals were analyzed using the MIXED procedure of SAS (v. 9.1, SAS Inst. Inc., Cary, NC, 2003). The FEC were $\log$ transformed $(\operatorname{Ln}(\mathrm{FEC}+15))$ in order to normalize the variances. The model included the fixed effects of periods (corresponding to the 2 weeks of measures after adaptation to the diet), parasitological status (PS, infected vs non-infected), diet, and diet $\times$ PS, with the effect of animals as random effect. Significance was declared at $\leq 5 \%$ of probability; comparisons between means were tested by the least squares means procedure with adjustment for multiple comparisons (Tukey-Kramer).

\section{Results}

The compositions and nutritional values of the supplements and the fresh grass are shown in Table 1 . There was a dietary effect on FEC (Table 2, $p=0.022$ ) with the highest value of FEC in the CC diet. No difference was observed between Ban and FG diets for FEC. A significant interaction between PS and diet was observed on PCV, with the lowest PCV in the CC diet of the infected group (Table 2, $p=0.0003$ ). No difference was observed between Ban and FG diets for PCV in the infected group. There was no effect of diet on PCV in the noninfected control groups.

There was a dietary effect on water intake and an interaction between PS and diet on the DMI (Table 3, $p<0.0006$ ). The highest water intake was observed with the CC diet. The DMI decrease significantly in the infected groups whatever the diet. The highest DMI reduction was observed in the FG diet (-66\% compared with -47.5 and $-51 \%$ in the Ban and the CC diets, respectively). The only significant interaction between diet and PS was observed on CP digestibility (Table $3, p=0.0024$ ). The $\mathrm{CP}$ digestibility decreased significantly in the infected groups whatever the diet. The highest reduction was observed in the Ban diet $(-59.2 \%$ compared with -12.7 and $-36.2 \%$ in the CC and the FG diets, respectively). No difference between DM, OM, and NDF digestibilities was observed between the Ban and the FG diets, but a reduction was observed in the infected groups whatever the diet (Table 3, $p>0.05$ ). The highest digestibility of $\mathrm{DM}, \mathrm{OM}$, and NDF was observed in the CC $\operatorname{diet}(p<0.005)$. The reduction of DM, OM, and NDF digestibilities ranged from -15.6 to $-5 \%$ with no significant difference between diets. In the non-infected groups, the highest ADG was in the $\mathrm{CC}$ diet $(p=0.0001)$. The ADG of the Ban and the FG diets in the control non-infected groups was low. A significant decrease of the ADG was observed in the infected groups whatever the diet $(p=0.0001)$. Weight lost was observed in infected groups of the Ban and the FG diet ( -4.6 and $-25.3 \mathrm{~g} /$ day, respectively).

\section{Discussion}

The beneficial effect of an improved nutritional status of small ruminants on GIN infection is one of the most easy to implement alternatives to anthelmintics. Numerous studies have investigated the effect of the quality and/or the quantity of feed supplements (in protein and/or energy) on the host response (Houdijk 2012; Torres-Acosta et al. 2012). According to Houdijk (2012), host resistance is mostly affected by metabolizable protein scarcity and moderately to metabolizable energy. Thus, higher protein diets should allow a better control of GIN infection in grazing small ruminants. However, during the last decades, feed costs have tended to increase, affecting the profitability of livestock production, including small ruminants. A step toward recommendation of nutritional strategies allowing a better control of 
Table 2 Least squares means of FEC and PCV of Creole kids infected with an oral single dose of 500 third-larva stage (L3) $/ \mathrm{kg}$ BW of Haemonchus contortus and Trichostrongylus colubriformis or not and feed with three different diets

\begin{tabular}{|c|c|c|c|c|c|c|c|c|c|c|}
\hline & \multicolumn{2}{|l|}{$\mathrm{CC}$} & \multicolumn{2}{|l|}{ Ban } & \multicolumn{2}{|l|}{ FG } & \multirow[b]{2}{*}{ SEM } & \multicolumn{3}{|l|}{$p$ value } \\
\hline & I & NI & I & NI & I & NI & & Diet & PS & Diet $\times$ PS \\
\hline FEC & $3783 a$ & - & $3302 b$ & - & $3128 b$ & - & 750 & 0.022 & - & - \\
\hline PCV & $19 a$ & $26 b$ & $22 \mathrm{c}$ & $26 b$ & $22 \mathrm{c}$ & $29 d$ & 2.0 & 0.0001 & 0.0001 & 0.0003 \\
\hline
\end{tabular}

Univariate analysis of FEC and PCV data. LS means with different lowercase letters within lines are significantly different $(p<0.05)$

$C C$ commercial concentrate, fresh grass supplemented with commercial concentrate, Ban dried banana, fresh grass supplemented with dried banana, $F G$ fresh grass non-supplemented, $I$ infected, period after experimental infection, $N I$ non-infected, period non-infected, $P S$ parasitism status, infected versus non-infected period, FEC fecal egg counts, eggs per gram of feces, $P C V$ packed cell volume
GIN is fine tuning of the feeding programs. Feeding trials with small ruminants have paid much attention on the effect of supplementation on the most susceptible physiological stages (i.e., young animals and periparturient does and ewes) and on the timing of supplementation (concomitant vs carry-over effects) (Knox et al. 2003; Houdijk et al. 2012). In tropical countries, feed resources are quite variables in quality and in quantity which lead to seasonal deteriorated nutritional status. In this study, we evaluated the short-term impact of changes in the nutritional status on the performances of growing kids during an established GIN infection. The DMI and digestibility increased significantly with the $\mathrm{CC}$ diet whatever the parasitological status (i.e., infected vs non-infected). The crude protein digestibility was lower in the infected groups but higher with the $\mathrm{CC}$ diet whatever the parasitological status. The NDF digestibility was also higher with the $\mathrm{CC}$ diet compared with the FG and the Ban diets. The lower digestibility of CP in infected animals is likely related with the already known hematophagous activity of both larval and adult stages of $H$. contortus and the subsequent mucosal hemorrhages coupled with the modifications of nitrogen metabolism induced by T. colubriformis (Williams and Palmer 2012). A poor reutilization of the absorbed nitrogen for de novo protein synthesis has been suggested, since a higher level of non-urea nitrogen excretion was measured in GIN-infected sheep (Williams and Palmer 2012). As many components of the immune system, such as immunoglobulins, muco-proteins, and cellular products such as leukotriennes, are proteinaceous, a decrease availability of amino acids for the metabolism would result to a decrease capacity to mount and maintain a protective immune response (Coop and Kyriazakis 1999). Indeed, it has been previously showed, by comparing groups of animals fed with different diets, that the prolificacy of GIN decreases with an improved nutritional status
Table 3 Least squares means of water intake, DMI, and apparent total tract digestibility of Creole kids infected with an oral single dose of 500 third-larva stage (L3)/ $\mathrm{kg}$ BW of Haemonchus contortus and Trichostrongylus colubriformis or not and feed with three different diets

\begin{tabular}{|c|c|c|c|c|c|c|c|c|c|c|}
\hline \multirow[t]{2}{*}{ Item } & \multicolumn{2}{|l|}{$\mathrm{CC}$} & \multicolumn{2}{|l|}{ Ban } & \multicolumn{2}{|l|}{ FG } & \multirow[b]{2}{*}{ SEM } & \multicolumn{3}{|l|}{$p$ value } \\
\hline & I & NI & I & NI & I & NI & & Diet & PS & $\begin{array}{l}\text { Diet } \times \\
\text { PS }\end{array}$ \\
\hline $\begin{array}{l}\text { Water intake } \\
(\mathrm{ml} / \text { day })\end{array}$ & $943 a$ & $949 \mathrm{a}$ & $586 \mathrm{~b}$ & $736 \mathrm{~b}$ & $541 \mathrm{~b}$ & $652 b$ & 54.0 & 0.0001 & 0.3021 & 0.6011 \\
\hline DMI (g/day) & $354 a$ & $717 b$ & $301 \mathrm{a}$ & $573 \mathrm{c}$ & $245 \mathrm{~d}$ & $553 \mathrm{c}$ & 58.5 & 0.0001 & 0.0001 & 0.0055 \\
\hline \multicolumn{11}{|c|}{ Digestibility ( $\mathrm{g} / \mathrm{kg}$ of) } \\
\hline $\mathrm{DM}$ & $723 a$ & $782 b$ & $598 \mathrm{c}$ & $709 a$ & $583 \mathrm{~d}$ & $661 \mathrm{a}$ & 13 & 0.0001 & 0.0001 & 0.23 \\
\hline $\mathrm{OM}$ & $727 \mathrm{a}$ & $784 b$ & $635 \mathrm{c}$ & $708 \mathrm{~d}$ & $621 \mathrm{c}$ & $654 d$ & 21 & 0.0001 & 0.0035 & 0.45 \\
\hline $\mathrm{CP}$ & $660 \mathrm{a}$ & $756 b$ & $209 \mathrm{c}$ & $512 \mathrm{~d}$ & $371 \mathrm{e}$ & $582 \mathrm{~d}$ & 38 & 0.0001 & 0.0001 & 0.0024 \\
\hline NDF & $600 \mathrm{a}$ & $674 b$ & $546 \mathrm{c}$ & $625 \mathrm{~d}$ & $578 \mathrm{c}$ & $653 d$ & 26 & 0.0365 & 0.0013 & 0.99 \\
\hline $\mathrm{ADF}$ & $479 a$ & $634 b$ & $507 \mathrm{c}$ & $574 d$ & $529 \mathrm{c}, \mathrm{d}$ & $615 b$ & 40 & 0.5028 & 0.0013 & 0.216 \\
\hline Amidon & $999 a$ & $996 a$ & $979 b$ & $991 b, a$ & - & - & 5.0 & 0.0310 & 0.5004 & 0.2355 \\
\hline $\begin{array}{l}\mathrm{ADG} \\
\text { (g/day) }\end{array}$ & $9.7 \mathrm{a}$ & $107.9 \mathrm{~b}$ & $-4.6 \mathrm{c}$ & $1.3 \mathrm{~d}$ & $-25.3 e$ & $7.4 \mathrm{a}$ & 6.0 & 0.0001 & 0.0001 & 0.0001 \\
\hline
\end{tabular}

Univariate analysis of water intake, DMI, and apparent total tract digestibility data. LS means with different lowercase letters within lines are significantly different $(p<0.05)$

$C C$ commercial concentrate, fresh grass supplemented with commercial concentrate, Ban dried banana, fresh grass supplemented with dried banana, $F G$ fresh grass non-supplemented, $I$ infected, period after experimental infection, $N I$ non-infected, period non-infected, $P S$ parasitism status, infected versus non-infected period, $D M I$ dry matter intake, $D M$ dry matter, $O M$ organic matter, $C P$ crude protein, $N D F$ neutral detergent fiber, $A D F$ acid detergent fiber, $A D G$ average daily gain 
in both sheep and goats (Hoste et al. 2016). We showed a significant effect of the diet changes on the FEC. Surprisingly, here, we showed that the diet with higher protein contents increased the intensity of the GIN infection measured trough a significant increase of the FEC correlated with a decrease of the PCV. However, in contrast with the lower nutritional status (i.e., FG and Ban diets), this diet maintained higher feed intake and digestibility and growth rate. In growing animals, a period of nutritional restriction induces a compensatory growth phenomenon which is the result of the optimization of different physiological functions of the animal with the objective to increase the growth rate (Hoch et al. 2003). In this study, the higher growth rate observed for the $\mathrm{CC}$ diets with a higher protein nutritional status could be the result of the poor protein nutritional status of the FG and the Ban diets which would have effects similar to a nutritional restriction.

Numerous studies suggest that response to an immunological challenge must be traded off against other physiological functions including growth (Shudo and Iwasa 2001; van der Most et al. 2011). Interestingly, the results of the present study suggest that the nutritional status could affect these physiological trade-offs between the growth and the immune response against GIN infection. The improvement of the nutritional status after a period with a deteriorated nutritional status during an establish GIN infection would improve the animal performance at the expense of the mechanism involved in the control of the infection. This finding could be of interest in tropical countries, where the deleterious effect of an establish GIN infection potentiated by seasonal deteriorated nutritional status could be counterbalanced by a protein-rich diet.

Acknowledgments The authors are grateful to the Gardel team in charge of the goat flock: R. Arquet, T. Kandassamy, W. Troupé, J. Gobardhan, and S.-A. Matou. This study was funded by the Project Agroecodiv (La Région Guadeloupe and Fonds Européens FEDER). WC was supported by a doctoral fellowship from la Région Guadeloupe and the animal Genetics Department of INRA.

\section{Compliance with ethical standards}

Statement of animal rights All the investigations presented in this study were approved by a local ethic committee (CEMEAAG, Comité d'Ethique en Matière d'Expérimentation Animale des Antilles et de la Guyane) and the French Ministry of Higher Education and Research.

Conflict of interest The authors declare that they have no conflict of interest.

\section{References}

Adams, C.A., 2006. Nutrition-based health in animal production, Nutrition Research Reviews, 19, 79-89

AOAC, 1997. Official Methods of Analysis of AOAC International, Association of Official Analytical Chemists, 16th edition,
Archimede, H., Bastianell, D., Boval, M., Tran, G., Sauvant, D., 2011. Tropical resources: availability and feed value, Inra Productions Animales, 24, 23-39

Athanasiadou, S., and Houdijk, J.G.M., 2010. Nutrition and Immunity in Animal Disease: Lessons from Parasitic Gastroenteritis, R.R. Watson, V. Preedy (Eds.) Dietary Components and Immune Function-Prevention and Treatment of Disease and Cancer. (Springer Humana Press), 63-74.

Athanasiadou, S., Houdijk, J.G.M., and Kyriazakis, I., 2008. Exploiting synergisms and interactions in the nutritional approaches to parasite control in sheep production systems, Small Ruminant Research, 76, 2-11

Aumont, G., Caudron, I., Saminadin, G., Xande, A., 1995. Sources of variation in nutritive values of tropical forages fron the Caribbean, Animal Feed Science and Technology, 51, 1-13

Aumont, G., R.Pouillot, and Mandonnet, N., 1997. Le dénombrement des éléments parasitaires: Un outil pour l'étude de la résistance génétique aux endo-parasites chez les petits ruminants, In Workshop final de l'AT CIRAD-MIPA 72/94, Guadeloupe, France

Bambou, J.C., Arquet, R., Archimede, H., Alexandre, G., Mandonnet, N., Gonzalez-Garcia, E., 2009. Intake and digestibility of naive kids differing in genetic resistance and experimentally parasitized (indoors) with Haemonchus contortus in two successive challenges, Journal of Animal Science, 87, 2367-2375

Bishop, S.C., 2012. Possibilities to breed for resistance to nematode parasite infections in small ruminants in tropical production systems, Animal, 6, 741-747

Charlier, J., van der Voort, M., Kenyon, F., Vercruysse, J., 2014. Chasing helminths and their economic impact on farmed ruminants, Trends in Parasitology, 30, 361-367

Colditz, I.G., 2008. Six costs of immunity to gastrointestinal nematode infections, Parasite Immunology, 30, 63-70

Coop, R.L., and Kyriazakis, I., 1999. Nutrition-parasite interaction, Veterinary Parasitology, 84, 187-204

Goldsmid, J.M., 1970. Studies on laboratory diagnosis of human filariasis, Journal of Clinical Pathology, 23, 632-\&

Hoch, T., Begon, C., Cassar-Malek, I., Picard, B., Savary-Auzeloux, I., 2003. Mechanisms and consequences of compensatory growth in ruminants, Productions Animales, 16, 49-59

Hoste, H., Torres-Acosta, J. F. J., Quijada, J., Chan-Perez, I., Dakhee, M. M., Kommuru, D. S., Muleller-Harvey, I., Terrill, T. H., 2016. Chapter Seven-Interactions Between Nutrition and Infections with Haemonchus contortus and Related Gastrointestinal Nematodes in Small Ruminants. In: B.G. Robin and S.-H. Georg Von (eds), Advances in Parasitology, 2016, (Academic Press), 239-351

Houdijk, J.G.M., 2012. Differential effects of protein and energy scarcity on resistance to nematode parasites, Small Ruminant Research, 103, $41-49$

Houdijk, J.G.M., Kyriazakis, I., Athanasiadou, S., 2012. Manipulating small ruminant parasite epidemiology through the combination of nutritional strategies, Veterinary Parasitology, $186,38-50$

Jackson, F., and Coop, R.L., 2000. The development of anthelmintic resistance in sheep nematodes, Parasitology, 120, S95-S107

Knox, M.R., Deng, K., and Nolan, J.V., 2003. Nutritional programming of young sheep to improve later-life production and resistance to nematode parasites: a brief review, Australian Journal of Experimental Agriculture, 43, 1431-1435

Papadopoulos, E., 2008. Anthelmintic resistance in sheep nematodes, Small Ruminant Research, 76, 99-103

Shudo, E., and Iwasa, Y., 2001. Inducible defense against pathogens and parasites: Optimal choice among multiple options, Journal of Theoretical Biology, 209, 233-247

Torres-Acosta, J.F.J., Sandoval-Castro, C. A., Hoste, H., AguilarCaballero, A. J., Camara-Sarmiento, R., Alonso-Diaz, M. A., 
2012. Nutritional manipulation of sheep and goats for the control of gastrointestinal nematodes under hot humid and subhumid tropical conditions, Small Ruminant Research, 103, 28-40

van der Most, P.J., de Jong, B., Parmentier, H. K., Verhulst, S., 2011. Trade-off between growth and immune function: a meta-analysis of selection experiments, Functional Ecology, 25, 74-80
Vansoest, P.J., Robertson, J.B., and Lewis, B.A., 1991. Methods for dietary fiber, neutral detergent fiber, and nonstarch polysaccharides in relation to animal nutrition, Journal of Dairy Science, 74, 3583-3597

Williams, A.R., and Palmer, D.G., 2012. Interactions between gastrointestinal nematode parasites and diarrhoea in sheep: Pathogenesis and control, Veterinary Journal, 192, 279-285 